\title{
Circulating immune cells in patients with surgically resected nonfunctional pancreatic neuroendocrine tumors
}

\author{
Zeljka Jutric $^{1}$, Jan Grendar ${ }^{1}$, Benjamin Cottam ${ }^{1,2}$, Chet Hammill ${ }^{3}$, Ronald Wolf ${ }^{3}$, Paul Hansen ${ }^{3}$, Marka Crittenden ${ }^{1,2,3}$, \\ Michael Gough ${ }^{1,2,3}$, Pippa Newell ${ }^{1,2,3^{*}}$
}

From 30th Annual Meeting and Associated Programs of the Society for Immunotherapy of Cancer (SITC 2015) National Harbor, MD, USA. 4-8 November 2015

\section{Background}

There is debate regarding whether surgical resection and/or lymphadenectomy are indicated for small nonfunctional pancreatic neuroendocrine tumors (PNETs). Myeloid cell population expansion in peripheral blood has been correlated with clinical stage of patients with solid tumors. We aim to determine if blood sampling can be used as a predictor of malignant potential in nonfunctional PNETs.

\section{Methods}

We prospectively measured cell counts in 29 patients with PNET using flow cytometry of fresh whole blood before and after surgery, including CD3+, CD8+, and CD4+ T cells; monocytes; and granulocytes. Correlations were sought with known clinical markers of malignant potential such as tumor size, grade, number of positive lymph nodes, and TNM stage using t-test and one-way ANOVA analysis (STATA Inc).

\section{Results}

In this small cohort of patients, there were no differences in circulating immune cell counts between patients with lymph node metastases versus those without, nor in patients with tumors $>2 \mathrm{~cm}$, nor in those patients with high grade tumors. Interestingly, patients with lymph node metastases had a significant decrease in number of circulating CD8+ $\mathrm{T}$ cells post operatively when compared to those with negative lymph nodes $(\mathrm{p}=0.013)$. There was a similar decrease in monocyte count post operatively in patients with positive versus

${ }^{1}$ Providence Cancer Center, Portland, OR, USA

Full list of author information is available at the end of the article negative lymph nodes that did not reach significance $(\mathrm{p}=0.056)$.

\section{Conclusions}

Our data do not provide evidence that circulating immune cell populations can be used as biomarkers of lymph node positivity or of malignant potential in PNET prior to resection.

\section{Authors' details \\ ${ }^{1}$ Providence Cancer Center, Portland, OR, USA. ${ }^{2}$ Earle A. Chiles Research Institute, Portland, OR, USA. ${ }^{3}$ The Oregon Clinic, Portland, OR, USA.}

Published: 4 November 2015

doi:10.1186/2051-1426-3-S2-P140

Cite this article as: Jutric et al.: Circulating immune cells in patients with surgically resected nonfunctional pancreatic neuroendocrine tumors. Journal for ImmunoTherapy of Cancer 2015 3(Suppl 2):P140.

Submit your next manuscript to BioMed Central and take full advantage of:

- Convenient online submission

- Thorough peer review

- No space constraints or color figure charges

- Immediate publication on acceptance

- Inclusion in PubMed, CAS, Scopus and Google Scholar

- Research which is freely available for redistribution 